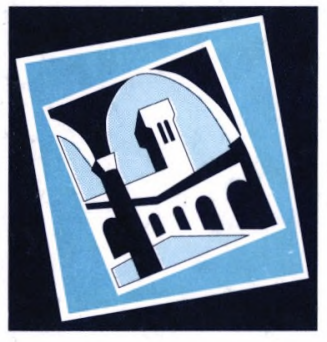

EUROPEAN UNIVERSITY INSTITUTE The Robert Schuman Centre

\title{
Environmental Agreements A New Instrument of Environmental Policy
}

\section{ECKARD REHBINDER} EUR 


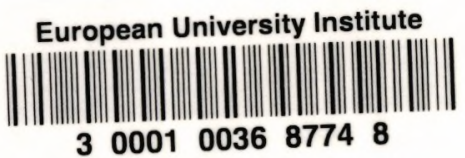

30001003687748 


\section{Jean Monnet Chair Papers}

Rehbinder: Environmental Agreements

A New Instrument of Environmental Policy 


\section{Jean Monnet Chair Papers}

\section{5}

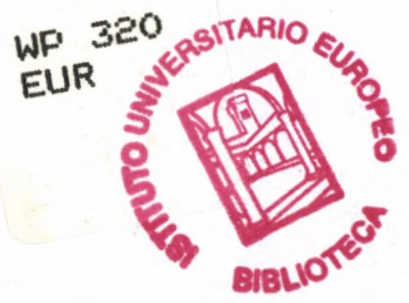

\section{The Jean Monnet Chair}

The Jean Monnet Chair was created in 1988 by decision of the Academic Council of the European University Institute, with the financial support of the European Community. The aim of this initiative was to promote studies and discussion on the problems, internal and external, of European Union following the Single European Act, by associating renowned academics and personalities from the political and economic world to the teaching and research activities of the Institute in Florence. 


\section{Jean Monnet Chair Papers}

\section{Environmental Agreements \\ A New Instrument of Environmental Policy}

\section{ECKARD REHBINDER}

1997

The Robert Schuman Centre at the European University Institute 
All rights reserved.

No part of this paper may be reproduced in any form without permission of the author.

c)Eckard Rehbinder

Printed in Italy in August 1997

European University Institute

Badia Fiesolana

I-50016 San Domenico (FI)

Italy 


\section{Table of Contents}

I. The need for self-regulation

p. 7

II. Some facts about environmental agreements in the EC member states

p. 13

1. Occurrence and structure of agreements

p. 13

2. Experience in the Netherlands and in Germany

p. 17

a) The Netherlands

p. 17

b) Germany

p. 20

p. 23

III. Evaluation

p. 23

1. The problem of appropriate evaluation criteria

p. 24

2. Stakeholder views

p. 26

3. Arguments

p. 26

a) Environmental effectiveness

p. 29

b) Efficiency

p. 30

c) Innovation

p. 31

d) Conformity with the legal system

p. 34

e) Environmental agreements and the political system

p. 35

IV. Legalization of environmental agreements?

Biographical Note

p. 37 


\section{The need for self-regulation}

In implementing its objectives, modern environmental law primarily employs regulatory strategies (command-and-control regulation), although there has always been a certain mix with other instruments such as subsidies, taxes, information, negotiation and moral suasion. This pattern of regulation has been favoured for various reasons. One reason for the predominance of administrative regulation is the tradition of police law which is the source of modern environmental law. Furthermore, administrative regulation is deemed to be effective, i.e. to ensure that the environmental quality goals are met. Finally it provides for participation of the public, transparency of agency decisions and political accountability of administrators; hence, administrative regulation embodies both legitimacy and a certain democratic element.

However, in recent years command-and-control regulation has to an ever increasing extent been criticised on the grounds that it is inefficient due to its neglect of individual costs of pollution control and prevention, hampers innovation, and, as a result of implementation and enforcement deficits that are inherent in this type of regulation, does not even achieve its environmental objectives. In particular, it is felt that administrative regulation is not a suitable instrument for implementing the goals of sustainable development - the modern paradigm of environmental policy. Also, there is a definite trend in public administration from juridical towards instrumental rationality, from application of law towards goal-achievement which at least weakens the position of law as the primary instrumental means of environmental policy. Therefore, a certain tendency towards deregulation of environmental policy has emerged, although administrative regulation still is clearly dominant.

The primary means of deregulation offered by critics of administrative regulation are economic instruments such as taxes, charges and tradeable permits. In the context of global climate policy, $\mathrm{CO}_{2}$ taxes have been introduced in some European countries and are widely discussed in other countries. However, there still is a large gap between the demands for greater reliance on economic instruments and political reality. The introduction of such instruments has met with much political resistance; and doubts have been raised as to whether economic instruments can really be associated with the program of deregulation. Indeed, contrary to the common understanding of economists, while economic instruments offer the market participants a relatively high degree of flexibility, they still are associated with the paradigm of 
the hierarchical authority of the state and hence, like command-and-control regulation, also are instruments of an interventionist environmental policy. They require the setting of concrete mandatory environmental protection or precaution targets by the state, and they impose on industry obligations to pay certain amounts of money or to acquire pollution rights if they want to emit waste substances or release harmful products into the environment.

There also are doubts as to whether economic instruments are a suitable, generally applicable means of a "proactive" environmental policy which aims at a sustainable structure of societyl. Since it is not always possible to formulate precise, enforceable environmental quality targets, proactive environmental policy must at least to some extent rely on social learning triggered by mere guidance as to the general direction of intended change. The need for proactive environmental policy lies in the enormous complexity and longterm nature of modern environmental policy, especially sustainability policy. Widespread scientific uncertainty about the existence and extent of risks to the environment and the regeneration capacity of natural resources, the complexity of potential adverse impacts of environmental policy measures on industry and the labour market, the distributional problems associated with sustainability policies, the need for achieving far-reaching structural change of the economy as well as fundamental change in the society's value system - all these factors render instrumental (means-ends) rationality at least problematic and suggest proactive environmental policy as an alternative or at least supplement. This is especially true where, as is presently the case almost everywhere in Europe, the ambitious goals of sustainable development are confronted with the challenge of a deep-going economic crisis. Economic instruments may be ideal under the perspective of allocative efficiency. However, they may have disruptive effects on the economy and be associated with high adjustment costs, especially cause considerable shifts of capital from one economic sector to another, promote dislocation of industry to foreign countries and increase unemployment. Moreover, economic instruments are not capable of steering the behaviour of potential polluters, especially process and product innovation, of itself into an environmentally-friendly direction. The mere knowledge of potential polluters that in case of later environmental problems the state could intervene with regulatory or economic instruments is not a

1 For the notion of proactive environmental policy see V. von Prittwitz, "Gefahrenabwehr - Vorsorge - Ökologisierung. Drei Idealtypen präventiver Umweltpolitik", in: U. Simonis (ed.), Präventive Umweltpolitik, 1988, p. 49-64; T. O'Riordan, "Anticipatory Environmental Policy", ibidem, p. 65-76; G. Fülgraff \& J. Reiche, "Proaktive Umweltpolitik", in: Festschrift von Lersner, 1990, p. 103-114. 
sufficient incentive for an "efficiency revolution" and other forms of structural change of the economy needed for achieving sustainability.

Self-regulation is a possible response to deficiencies both of administrative regulation and economic instruments ${ }^{2}$. At first glance, this seems paradoxical. There does not seem to be a reason why firms who cannot be caused to behave in a sustainable way by administrative regulation or object to the imposition of economic instruments should be willing to change their behaviour through voluntary self-regulation. The answer can be found on two levels of argument.

In the first place, self-regulation is attractive because it grants firms greater flexibility in the timing and design of adjustment measures and allows for an equitable distribution of adjustment burdens to participating firms. Moreover, the fact that industry is in some way or other also involved in the goal-setting process promotes compliance.

Secondly, since "pure", i.e. strictly autonomous, self-regu-lation runs counter to the interests of the relevant actors and is contrary to the logic of a market economy, the state exercises a certain degree of influence or even pressure towards solving existing or anticipated environmental problems by self-regulation. Environmental self-regulation occurs either in the "shadow of hierarchical authority" 3 , i.e. under the threat of adopting administrative or economic regulation or as a result of institutional or organisational arrangements set by the state. "Pure" self-regulation is rare. Normally, the state attempts to influence the behaviour of firms by setting indicative environmental policy targets and/or it creates an informational or organisational framework that is designed to promote a sustainable behaviour of these actors. It is hoped - and research on environmental innovations by industry seems to confirm this assumption - that in the course of their activities, they of themselves then consider the environmental consequences of their behaviour and achieve or make use of process or product innovation that reduces environmental degradation and resource consumption. Instead of orders given by the state or the pressure of money the state relies on incited consensus, information, and

2 For the following text see E. Rehbinder, "Self-regulation by Industry", in: G. Winter (ed.), European Environmental Law, 1995, p. 239, at 240-242; but also P. Lascoumes \& J. Valluy, Les activités publiques conventionnelles - un nouvel instrument de politique publique? L'exemple de la protection de l'environnement industriel, EUI Working Papers RSC No. 96/16, 1996, at 2, 4.

3 F. Scharpf, "Positive und negative Koordinierung in Verhandlungssystemen", in A. Héritier (ed.), Policy-Analyse - Kritik und Neuorientierung, PVS-Sonderheft 24/1993, p. 57 , at 71 . 
organisation. If one stresses the - necessary - framework conditions that make environmental self-regulation possible, rather than the resulting act of selfregulation, one can speak here of "soft" instruments of environmental policy 4 .

This analysis is supported by the findings of various schools of political and legal science which all state a loss of the hierarchical authority of the state and a trend towards establishing multipartite policy networks composed of the state and various societal actors. Their function is to use the innovation potential of all participating actors and jointly solve the complex and long-term problems of modern society, including the formulation and implementation of environmental policy5. This does not mean that hierarchy disappears. The state remains a "privileged" actor who represents the public interest and has a moderating function. Moreover, it can take recourse to coercion where the network process proves to render unsatisfactory results. However, the stereotype paradigm of the state as the instance of comprehensive control of society and the classical separation of state and society are modified in the sense that state action relating to complex and long-term problems of environmental policy to an ever increasing extent takes place in the framework of relatively stable dehierarchised exchange, bargaining and cooperation systems 6 . Apart from policy networks there are also mechanisms of "global", less focussed steering of self-regulation by informational and organisational intervention, such as the eco-audit scheme or requirements of firms to nominate environmental officers and directors7. These mechanisms do not aim to solve a specific problem, but, rather, promote capacity-building.

The need for some state involvement in the process of self-regulation has important implications for its use as an instrument of environmental policy.

4 See W. Rengeling, Das Kooperationsprinzip im Umweltrecht, 1988, p. 3-14.

5 See, e.g. C. Böhret, "Zur Handlungsfähigkeit des funktionalen Staates der spätkapitalistischen Industriegesellschaft", in: B. Kohler-Koch (ed.), Staat und Demokratie in Deutschland, 1992, p. 116-129; C. Offe, "Die Staatstheorie auf der Suche nach ihrem Gegenstand", 1 Jahrbuch für Staats- und Verwaltungswissenschaft, p. 309, at 317 (1987); E.H. Ritter, "Umweltpolitik und Rechtsentwicklung”, 6 Neue Zeitschrift für Verwaltungsrecht 929, at 937 (1987); M. Jänicke, Vom Staatsversagen zur politischen Modernisierung, Festschrift Hartwig, 1993, p. 63-77; F. Schuppert, Rückzug des Staates?, 48 Die Öffentliche Verwaltung 761, at 763 (1995).

6 F. Scharpf, "Positive und negative Koordinierung in Verhandlungssystemen", in A. Héritier (ed.), Policy-Analyse - Kritik und Neuorientierung, PVS-Sonderheft 24/1993, p. 57-83; R. Mayntz, "Policy-Netzwerke und die Logik von Verhandlungssystemen", ibd. p. 39-56; P. Hassenteufel, "Do Policy Networks Matter?", in P. Le Galès (ed.), Les réseaux de l'action publique, 1995, p. 91-272.

E. Rehbinder, supra note 2, at 262-265. 
Self-regulation supplements administrative and economic regulation in that it aims to achieve policy objectives that are beyond the reach of, or cannot as effectively be achieved by, administrative or economic regulation. It assumes the existence of a sophisticated environmental policy, a high level of baseline regulation and a sufficient organisation of the environmental administration. Where these prerequisites are not met, recourse to self-regulation would be quite dangerous.

Self-regulation can avoid frictions in the economic process and thereby efficiency and innovation losses normally associated with administrative regulation, but to a certain extent also with economic instruments. The price paid for this advantage lies in the "exchange model" of self-regulation. Environmental policy objectives may be accomplished to a lesser degree or with lesser certainty than (theoretically) expected as a result of administrative or even economic regulation; this loss of accuracy of goal achievement is a possible, although not necessary result of voluntariness whose degree varies according to the relevant soft instrument used. Therefore, self-regulation as a rule cannot - or at least should not - be used for the prevention of clearly unacceptable risk, but, rather, in areas where environmental risks or resource consumption below the level of unacceptability shall be reduced for precautionary reasons. However, given the difficulty in delimiting these two types of risk, this only is a rule of thumb.

Some authors 8 deny that self-regulation, especially in the form of environmental agreements, constitutes an alternative instrument of environmental policy, advancing several arguments for this proposition: Where environmental agreements are used as a substitute for regulation they involve negotiation on targets and hence are not an instrument to achieve targets; they are not alternative insofar as they only supplement administrative or economic regulation or, where consensus on an agreement depends on threats of future administrative regulation or taxation, there often is no political choice because administration or economic regulation fails due to the veto power of interest groups; and finally an open balancing of the costs and benefits of environmental agreements compared to other instruments does not normally take place. The authors suggest that the greater "visibility" of environmental agreements may just be a product of new tendencies of social science research 
such as neocorporatism, policy network analysis, coalition theory and implementation research ${ }^{9}$ and has also to do with ideological developments 10 .

I am not convinced that these arguments require a fundamental reorientation of the conventional interpretation of the phenomenon of environmental agreements: Negotiation on targets also occurs in the decision-making process regarding administrative regulation or ecotaxes; environmental agreements which are used for supplementing administrative regulation nevertheless are an alternative to concretised rules, while the occurrence of threats with regulation sheds some light on particuliarities of consensual instruments but does not vitiate the independent character of environmental agreements as an instrument; the reverse argument relating to the lack of a real political choice could be applied to any of the competing instruments for denying their quality as an instrument; and finally, possible deficiencies as to open balancing the benefits and disadvantages of public action are not limited to environmental agreements.

The following remarks will be limited to a single important instrument of self-regulation, namely environmental agreements (in the broadest sense) that are used as a substitute, precursor or at least complement for administrative regulation. 


\section{Some facts about environmental agreements in the EC member states}

\section{Occurrence and structure of agreements}

Throughout Europe, there is a certain trend towards use of contractual techniques of environmental policy, although the extent to which states resort to such techniques is quite varied. In the last 15-20 years environmental agreements have quite frequently been used as an instrument of environmental policy in the Netherlands and Germany, to a lesser extent also in Austria and Denmark, the other EC member states trailing behind. The agreements cover such diverse fields as the reduction of effluents by existing sources, the reduction of toxic emissions, the prevention and recycling of waste, the phasing out of hazardous substances in products and the export of pesticides.

Following the mandate of the 5th Environmental Action Program, the European Community has more recently also become active in this field. In 1995 , it commissioned an empirical investigation covering the whole Community whose purpose was to generate information as to the occurrence and structure of, and attitudes of major policy players towards, environmental agreements and evaluate their success. This investigation 11 is the basis of part of the following analysis. Relying on the findings of this investigation as well as other pertinent information, at the end of November 1996, the Commission addressed a Communication on environmental agreements to the Council and the European Parliament and one week later issued a Recommendation on environmental agreements for implementing directives of the Community 12 .

A major problem of delimiting the scope of the investigation and, as later events have shown, also of substantive policy towards environmental agreements has been the definition of agreement. Environmental agreements may be legally binding on the parties (environmental contracts or covenants). They may also - and in practice often are - non-binding contracts or informal "gentlemen's agreements". In some EC member states, especially Germany and also Austria, public authorities even are not a formal party to the agreement. Rather, industry issues a formally unilateral declaration - a "selfcommitment" -, which, however, often is based on the initiative of the state, is

11 Consulting Engineers and Planners, Study on Voluntary Agreements concluded between Industry and Public Authorities in the Field of the Environment, Final Report 1997 (not yet published).

12 COM (96) 561 final; Recommendation 96/733/EC, 1996 O.J. No. L 333/59. 
the product of negotiations between the state and industry and is addressed to, and often expressly recognized by the state. Finally, there may be purely internal self-commitments and codes of practice which are not directly related to state action; since they are not an instrument of environmental "policy" they are not included here13. As regards the parties to the agreement, on the side of industry, indu-trial associations rather than the membership firms often conclude the agreement. If the latter do not formally adhere to the agreement, this raises some questions of representation and loyalty and diminishes the binding or de facto binding effect of the agreement.

The investigation shows that in Germany, Austria, Belgium, France and the United Kingdom non-binding agreements and self-commitments prevail, while in the Netherlands and Portugal binding contracts are the rule and in Denmark and Sweden both types of agreement are almost evenly used. In spite of this quite varied pattern, in its Recommendation on environmental agreements 14 , the European Commission shows a clear preference for binding agreements, heavily relying on the recent Dutch example which is very close to negotiated rule-making. It is doubtful whether this quite unilateral preference for a particular type of environmental agreement is appropriate if one envisages using the potential of self-regulation to its fullest extent in all EC member states with their different political-administrative cultures and different experience in using consensual approaches.

Reliance on environmental agreements in the EC varies considerably from country to country. There are countries such as the Netherlands and Germany where environmental agreements have become an important complementary instrument of environmental policy in the last 15-20 years. In the Netherlands, 107 agreements have been inventorised for this period15. For Germany, the figure is 93 . This latter figure represents some double-counting as regards the $\mathrm{CO}_{2}$ self-commitment of the German Industry of 1995 and its 1996 amendment. The 15 and 19 sectoral self-commitments, respectively, that have been issued under the umbrella of this comprehensive agreement and its amendment and are an integral part of it have been included. The adjusted

13 For an even more detailed taxonomy see P. Lascoumes \& J. Valluy, supra note 2, at 617 , who, however, also include non-regulatory agreements and pure (internal) selfregulation; see also M. Potier, "Les accords volontaires sur l'environnement", L'observateur de l'OCDE No. 189, août-septembre 1994, 8, at 19; M. Bulling, "Kooperatives Verwaltungshandeln (Vorverhandlungen, Arrangements, Agreements und Verträge) in der Verwaltungspraxis", 42 Die Öffentliche Verwaltung, 277, at 280-281 (1989).

14 Supra note 12.

15 The figure even is too low by at least 7 agreements due to a narrow definition of "voluntariness", excluding agreements fostered by public campaigns. 
figure would be about 60 self-commitments. Austria (20), Denmark (16), Italy (11), Sweden (11) and Portugal (10) form a middle group, while countries such as the United Kingdom, France, and Spain have less than 10 agreements 16. There even is one EC member state, namely Greece, where apparently no environmental agreement has ever been concluded and two other member states where the figures are far below 5 (Finland and Ireland).

An explanation for this marked difference is difficult. One factor may be the stringency and ambition of national environmental policy. In order to achieve further progress behind the background of ambitious precautionary and sustainability targets on the one hand, and economic problems on the other, these countries take recourse to environmental agreements in order to overcome political obstacles and keep momentum in their environmental policy.

Another factor is the political-administrative culture of a given country, especially the degree of legalisation of a given society as well as its basic value orientation. In countries that have a legalistic concept of command-andcontrol regulation, emphasise legal accountability of administrators, provide for extensive judicial protection of diffuse interests and where the value system of society is adversarial, there is less room for contractual instruments of environmental policy than in countries where formal rule-of-law thinking plays a somewhat less prominent role and the political decision-making process is either more technocratic or more consensus-oriented 17.

Finally, a firm commitment of a national government to deregulation, either for improving the competitive situation of the national industry on the world market or for entangling industry in the implementation process, may be a contributing factor.

Environmental agreements cover many sectors of environmental policy. However, especially recently, product waste-related agreements (batteries, end-of-life vehicles, recycling of other product waste) are most frequent,

16 In the United Kindgom a more generous definition of voluntary agreement would have increased this number by about 4-5 agreements. - The Portuguese agreements all relate to compliance with existing law.

17 For the relevance of policy styles see D. Vogel, "National Styles of Regulating Environmental Policy in Great Britain and the United States", 1986; J. Richardson (ed.), Policy Styles in Western Europe, 1982. However, the marked difference between the Netherlands and the United Kingdom shows that generalisations are difficult. It could well be that a strong tradition of regulatory bargaining makes reliance on environmental agreements unnecessary. 
which may be explained by the high complexity of this field and the lack of a regulatory tradition. Product-related agreements (phase out, product improvement, packaging and labelling) are of almost equal importance. Agreements whose primary purpose is the reduction of emissions from industrial facilities play a less prominent role, even if one considers the more recent agreements in the field of $\mathrm{CO}_{2}$ reduction and energy efficiency. However, this classification is based on the titles of the agreements. It must be qualified to a certain extent if one includes secondary effects caused by achieving the primary purpose of an environmental agreement; then emission reduction would become more important.

Environmental agreements often contain reporting and monitoring provisions. These provisions are a response to a fundamental weakness of at least non-binding agreements, but also exist in binding agreements. Although there may be a basic trust between public authorities and industry, such requirements are considered as indispensible for ensuring that the agreement is effective and credible and gains sufficient public acceptance. Older and less complex agreements often only contain simple reporting requirements. However, more recent and more complex agreements may provide for sophisticated monitoring accompanied by some verification mechanism.

Freerider provisions are less frequent. They may address problems presented by internal freeriders, namely firms that - through their membership in the contracting association - are indirect parties to the agreement. In this case transparency clauses (identifying reporting and monitoring) will often suffice to detect such freeriders and deter them from evading the agreement (although industry takes the view that these precautionary measures are unnecessary and only serve to convey credibility of the agreement to the public at large). External freeriders, especially importers, may pose more serious problems to the functioning of an agreement. However, unless their adherence to the agreement cannot be enforced or otherwise ensured, the participating firms have a strong market position or can expect a competitive advantage from the agreement (e.g., in case of product improvement) there is no easy remedy. In a German agreement concerning solvents in paints and varnishes one provided for the exercise of moral suasion (public demands on outsiders to comply with the rules established by the agreement). Probably negotiation will not lead to agreement if the risks of freerider competition are considered to be too high, but miscalculations of the relevant actors cannot be ruled out. 


\section{Experience in the Netherlands and in Germany}

\section{a) The Netherlands}

The Netherlands have the most extensive experience with regulatory agreements 18 . More than 100 agreements have been concluded beginning in the 1980s. In the first generation of agreements that started in the second half of the 1980s, an ad-hoc approach dominated; the relevant agreements mainly concerned particular products. Many of the second generation of agreements concluded after the adoption of the First Environmental Policy Plan (NEPP) in 1989 concerned sectors of the economy that have been designated as priority target groups for implementing environmental quality objectives laid down in the plan. One basic approach developed in the Environmental Policy Plan of 1989 was the idea of "internalisation"; the sectors composing the target groups should agree with the state on the relevant policy options and available means and voluntarily assume a fair share of reducing pollution originating with the target group (strategic discussion) and, as a result of this discussion, they could formulate their own environmental plans for meeting the required goals through self-regulation 19 . This explains the growing trends towards reliance on environmental agreements in the Netherlands in the 1990s.

As far as their legal form is concerned, the older agreements were all simple gentlemen's agreements, while more recently a binding contractual form has normally been used, although gentlemen's agreements still exist and binding contracts also contain mere declarations of intent. As with the strategic discussions, negotiations on environmental agreements (concluded by the

18 See J. Peters, "Voluntary Agreements between Government and Industry, The Basic Metal Covenant as an Example", in: J. van Dunné (ed.), Environmental Contracts and Covenants: New Instruments for a Realistic Environmental Policy?, 1993, p. 19-31; J. van den Broek, "Covenant and Permit in the Dutch Target Group Consultation", in: J. van Dunné (ed.), ibid., p. 33-43; J. Biekart, "Environmental Covenants Between Government and Industry in the Netherlands", 4 RECIEL 141- 149 (1995); I. Koppen, "Regulatory Negotiation in the Netherlands: The Case of Packaging Waste", in: P. Knoepfel (ed.), Lösung von Umweltkonflikten durch Verhandlung, 1994, p. 153-169; R. Gerits \& J. Hinssen, "Environmental Covenant for the Oil and Gas producing Industry: A Valuable Policy Instrument?", 24 Envt'l Pol. \& Law 323-329 (1994); N. Koeman, "Bilateral Agreements Between Government and Industry in Dutch Environmental Law", 2 EELR 174, at 183-184 (1993).

19 M. Hajer, "Furthering ecological responsibility through "verinnerlijking": the limits to a positive management approach", in: G. Teubner, L. Farmer \& D. Murphy (eds.), Environmental Law and Ecological Responsibility, 1994, p. 167, at 174-182; I. Koppen, supra note 18 , at $158-161$. 
Ministry for Housing, Land-use Planning and the Environment) are subject to full participation of the public, especially environmental associations, and the Parliament may intervene 20. Many of the more recent agreements also comprise the stage of individual implementation at firm level via company implementation plans, including provision for translation of the plans into permit requirements. To this extent, the Dutch regulatory agreement is a hybrid between regulatory and compliance agreement, but also between consensual and regulatory technique.

The agreements mainly concern the reduction of emissions (e.g. VOC, $\mathrm{NO}_{\mathrm{x}}$ and $\mathrm{CO}_{2}$ from power plants, ammonia from cattle breeding), the cleaning up of contaminated soil underneath gasoline stations, product phase-out, waste policy (recycling of packagings, asbestos and plastics) and energy efficiency (so-called long-term agreements concluded by the Ministry of Economic Affairs providing for $20 \%$ improvement in 2000 compared to 1989).

The more complex agreements also contain control and monitoring mechanisms. A "steering group" composed of representatives of government and the involved industrial sector is responsible for supervising the performance of the participating firms and making proposals for eventual adjustment. The firms have to submit to the government annual company reports which state the progress made in implementing the company implementation plan. These are also open to the public.

An important example of the new generation of environmental agreement is the Basic Metals Covenant21. The Basic Metals Covenant was concluded between the Foundation for the Primary Metals Industry and the Environment and the major producers on the one hand, and the competent public authorities, especially the Ministry for Housing, Land-use Planning and the Environment, on the other. It is open to accession by firms that have not signed it. It is a binding contract which, however, is not substituted for the applicable legal provisions; rather, the agreement provides that the competent permit authorities shall consider its terms in granting and modifying permits.

20 I. Koppen, supra note 18, at 162-164; P. Gilhuis, Milieurecht op weg naar de jaren negentig, 1989, at 27-29; National Environmental Policy Plan Plus 1990, Annex 1, p. 1314. This is not true of agreements concluded by the Ministry of Economic Affairs.

21 See J. Biekart, supra note 18, at 145-147; J. Peters, "Voluntary Agreements between Government and Industry: The Basic Metal Covenant as an Example", in J. van Dunne, supra note 18, p. 19-23 (a summary of the agreement is reprinted at 285-308). 
The covenant uses an integrated approach, comprising all major emissions (air including CFCs and $\mathrm{CO}_{2}$, water, and soil including historic pollution), waste, radiation, noise, odours and industrial safety in the primary metals industry. It has two different kinds of provisions. The first part together with the annex constitutes the "Declaration of Intent" and the "Integral Environmental Target Plan" which sets reduction and to a certain extent quality targets for the whole industry. The reduction targets (base year 1985) are divided into interim and final targets. The parties commit themselves to achieve these targets. In the second place, the agreement contains provisions concerning the "translation" of the targets into requirements for individual firms through a "Company Environmental Plan", setting out the procedure for negotiating the plans and its minimum contents (status quo, presently used technology, state of the art, envisaged reductions). In view of the heterogeneous structure of the branch consisting of 36 large and medium-sized firms, the company plans are negotiated between individual firms and the competent authorities. However, the covenant grants the Industry Consultation Committee, a steering committee composed of representatives of the Primary Metals Foundation and the participating ministries, an important role in ensuring the compatibility of the company plans with the targets, in particular in seeing to it that the sum of the reductions provided in the company plans is equivalent to the targets. Moreover, the drafts of the company plans must be made public and are subject to public participation. If the competent authorities agree to the company environmental plan they endeavour to consider it in granting or modifying permits which means that unless there are cogent reasons to the contrary, the company plan will be practically binding. Otherwise, the existing regulations are applied; the same is true in case of violation of the plan. The firms must submit annual reports to the authorities in which they describe the progress made in achieving the targets set forth in the company plan. However, there is no independent verification mechanism.

On the basis of problem areas of a general nature such as economic and technological development, newly acquired knowledge and emission profiles of firms, the Industry Consultation Commitee may discuss and eventually propose adjustments of the Integrated Environmental Target Plan, especially in the form of a prolongation of the deadlines. These adjustments require the agreement of all parties to the covenant. To this extent the covenant, although formally binding, contains elements of a "soft" agreement.

The covenant is criticised on the grounds that, based on the company plans, it can be predicted that about 50 percent of the targets for the year 2000 will not be reached, the company plans do not describe presently used technology 
as well as the existing environmental policy of the relevant firm and therefore impede a comparative evaluation, the measures provided in the companny plans do not adequately reflect recent technology and there often are no deadlines set for reaching the targets.

\section{b) Germany}

In Germany, "self-commitments" rather than formal agreements are the normal form of concerted self-regulation by industry in the field of environmental policy22. Public authorities are not formally involved in these commitments which take the form of unilateral declarations of national branch associations or the national industry federation and in some cases of individual firms. However, these declarations are normally the outcome of intensive discussions with the competent ministries; more recently, but also sometimes in the past, these discussions have taken the form of veritable and long-lasting negotiations. Moreover, the declarations are addressed to the relevant public bodies, they are recognised by them in an informal way, for instance a press release, a press conference of the ministry concerned or correspondance, or even flanked by a "lean" regulation. Finally the relevant public bodies exercise a major degree of control over the achievement of the targets set by the declaration.

Industry has issued about 60 self-commitments (and some formal agreements) in the field of environmental policy since the early 1980s (excluding about 20 purely internal self-commitments that are not addressed to, and not recognised by, the relevant authorities). If one included the separate selfcommitments issued in the framework of the self-commitment of the German industry on protecting the global climate of 1995 and its amendment of 1996 , the figures would have to be increased considerably, that is up to more than 90. The number of self-commitments is relatively high, with major increases in the recent years. This has two interrelated reasons. First of all, there is a clear political stance of the Federal Government in favour of self-commitments. This stance corresponds to widespread demands by industry which opposes both administrative regulation and economic instruments. The other reason for the emergence of self-commitments is that in the present stage of widespread unemployment and a staggering economy environmental policy has a difficult position in conflicts with other policies; one can even say that

22 W. Rengeling, supra note 2, at 40-44; cf. E. Bohne, "Absprachen zwischen Industrie und Regierung in der Umweltpolitik", 8 Jahrbuch für Rechtssoziologie und Rechtstheorie 266, at 283 (1982); id., "Informales Verwaltungs- und Regierungshandeln als Instrument des Umweltschutzes", 75 Verwaltungsarchiv 343, at 361 (1984). 
the wind blows into the face of environmental policy. Self-commitments are considered as a way out of the impasse in which environmental policy is presently situated. This, of course, theoretically means that the pendulum may also swing back to administrative regulation. However, given the general tendency towards recognising the limits of regulation, it is not very probable that self-commitments will fall into disgrace in the foreseeable future, provided they can demonstrate an adequate degree of effectiveness as compared to administrative regulation on the one hand, market-based instruments on the other.

Among the more recent self-commitments, the declaration of the German Industry on protection of global climate of 1995 , as amended and expanded in 199623 , is of particular importance. It is seen as a test case for the effectiveness and acceptability of self-commitments as an instrument of environmental policy in lieu of command-and-control regulation. The original declaration contained a commitment of the German industry to reduce the specific $\mathrm{CO}_{2}$ emissions or specific energy consumption (i.e. emissions or energy per production unit) by $20 \%$ by the year 2005 , the base year being 1987; the amended declaration stiffens this commitment by choosing the year 1990 as base year, which means that most "windfall profits" in emission reductions from plant closures after the German reunification can no longer be credited. Moreover, in addition to the originally 15 industrial sectors, 4 new sectors joined the declaration. The new declaration contains a rather detailed and complex monitoring system which is supervised by an independent economic research institute. It is provided that the data generated shall also be made public.

The declaration is an "umbrella" declaration which is concretised by 19 individual self-commitments of various sectoral associations which describe the reduction potential and promise to take the best technical efforts to fully use this potential, in the second declaration also report on previous progress and indicate further measures envisaged. The whole system accounts for about $70 \%$ of industrial energy consumption and close to $100 \%$ of public electricity supply; moreover, due to the participation of the associations of the German gas and electricity supply industry and the municipal enterprises, it

23 See Erklärung der deutschen Wirtschaft zur Klimavorsorge, 1996 Umwelt 193-195; Selbstverpflichtungserklärung der Wirtschaft - Ein wichtiger Baustein des Klimaschutzprogramms, 1997 Umwelt 102-104; K. Rennings et al., Nachhaltigkeit, Ordnungspolitik und freiwillige Selbstverpflichtung, 1996, p. 203-219; for an appraisal of an advanced draft of the $\mathrm{CO}_{2}$ self-commitment see M. Kohlhaas, B. Praetorius et al., Selbstverpflichtungen der Industrie zur CO $\mathrm{C}_{2}$-Reduktion, 1994. 
indirectly comprises most households and small commercial consumers. Most self-commitments indicate quantitative targets which may be below, or beyond the general target of $20 \%$. Moreover, in contrast to the 1995 declaration, individual self-commitments do not only promise the reduction of specific $\mathrm{CO}_{2}$ emissions or the increase of specific energy efficiency; there are 15 commitments that are also couched in absolute terms.

The origin of the $\mathrm{CO}_{2}$ self-commitment was the desire of the German government to have something to present to the Berlin Conference that demonstrated the firm will of Germany to comply with its unilateral commitment of reducing $\mathrm{CO}_{2}$ emissions by $25 \%$ by 2005 . Since both the introduction of a $\mathrm{CO}_{2}$ and/or energy tax and the promulgation of the regulation for the reutilization of excess process heat mandated by the Federal Emission Control Act were very controversial, the self-commitment was seen as a compromise.

In the view of industry, the self-commitment presents important efficiency gains, its major advantage being the possibility of differentiating the respective commitments of the various industrial sectors according to their (average) cost structure and reduction/saving potential. It is argued that administrative regulation as well as environmental taxes would lead to uniform - or at least less differentiated - requirements or effects. However, there also is much criticism of the $\mathrm{CO}_{2}$ self-commitment. This criticism is mainly predicated on two grounds: that the obligations assumed by industry are soft, not really voluntary and contrary to the postulates of a market economy and that industry only promised $\mathrm{CO}_{2}$ emission reductions and energy savings that, considering the past development, will occur even without the self-commitment 24 . 


\section{Evaluation}

\section{The problem of appropriate evaluation criteria}

The assessment of environmental agreements has always been controversial and their increasing use in the recent past is seen by many not as a sign of the growing need for a flexible environmental policy that is considerate for the needs of the affected industry, but, rather, as a sign of regulatory weakness of the state.

The primary problem of an economic evaluation of contractual techniques is the development of an adequate reference system for comparing environmental agreements on the one hand, and administrative and economic regulation on the other. Of course, the economic theory of regulation has developed a set of criteria for assessing different instruments for implementing environmental policy, such as environmental effectiveness, (static) efficiency, impact on innovation (dynamic efficiency), consistency with the fundamental decision for a market economy, constitutionality, administrative feasibility, and distributional fairness 25 . The problem is how to make the comparison. In this respect, the orientation of economic theory at models seems to cause some methodological difficulties. The reference system of evaluation cannot be an idealized configuration of traditional or economic regulation, but, rather, the configuration that would have existed if normal procedures had been followed for introducing administrative regulation or economic instruments. It is not appropriate to compare a realistic contractual configuration with an idealized regulatory one 26 . Seen in this perspective, many of the economic arguments sustained against environmental agreements are less convincing so long as it cannot be shown that under the circumstances of the particular case administrative or economic regulation would have rendered a better result in relation to baseline emissions, the reduction potential and possible consumption of improvements by growth. Thus, it appears methodologically incorrect to take it for granted that the stringency of administrative regulation or economic instruments merely envisaged in a draft or project of the executive can serve as a standard for assessing an environmental agreement that is substituted for it. This is especially true where the targets and

25 See, e.g. D. Cansier, Umweltökonomie, 2nd ed. 1996, at 152; A. Endres, Umweltökonomie, 1994, at 100-101 with further references.

26 This is largely done by K. Rennings et al., supra note 23 , see, e.g., at 90-91, 101-102, $150-151,161,166,211,219,224-225$; B. Kohlhaas \& M. Praetorius, supra note 23, at 47-48; P. Lascoumes \& J. Valluy, supra note 2, at 20-28. 
design of administrative or economic regulation are politically very controversial, which often is the case where ultimately environmental agreements are concluded. Conversely, environmental agreements that merely supplement or stiffen existing administrative regulation should not automatically be considered as positive. It could well be that the existence of, or the negotiation on, an environmental agreement precludes the adoption of more stringent regulation. As far as I can see, generally applicable standards of comparison have not yet been developed. It is submitted that for the time being comparisons can only be made on a case-by-case basis using best professional judgement. This pragmatic modesty appears superior to the somewhat agnostic proposition to renounce to any substantive criteria and only ensure adequate procedures, the more so since the fundamental question of tertium comparationis cannot be really avoided by this way out.

This qualification does not apply to economic negotiation theory insofar as it analyses and/or predicts the outcome of negotiations on administrative regulation and environmental agreements based on the economic interests of the main players. Law and political science also have an easier task since they conceive the "real world" as the object of their research, either based on a set of fundamental values such as state of law, justice and procedural fairness (law) or applying criteria that aim at evaluating the functioning of decisionmaking systems (political science).

\section{Stakeholder views}

One of the main purposes of the empirical investigation already mentioned 27 was to learn more about the views of the main stakeholders - industry, public authorities and environmental associations - as to the pros and cons of environmental agreements. On the basis of the - somewhat divergent - answers to the questionnaires on the one hand and the interviews conducted on the other, one can say that both industry and public authorities are generally in favour of concluding agreements, while environmental associations are more reserved, however without rejecting them entirely.

Industry attaches greater importance to incentives produced by environmental agreements, while public authorities tend to emphasise barriers. Industry sees the benefits and incentives of environmental agreements in efficiency gains, the possibility of practical solutions, avoidance of regulation, partner-

27 Supra note 11. 
ship, flexibility, a say in policy making, competitive gains, reduced operating costs and quick implementation. The public authorities emphasize partnership, efficiency gains and competitive gains of industry. As for barriers to reliance on environmental agreements, industry attaches the greatest importance to the regulatory tradition, resistence to institutional innovation and a negative public perception, while public authorities emphasize a poor industry compliance record, the lack of power of sectoral associations over their members, the heterogeneous composition of a particular sector of industry, an excessive cost burden and negative public perception. Both groups consider distortion of competition, i.e. competitive advantages of foreign firms, as an important barrier. As for incentives offered to public authorities to enter into environmental agreements, both groups stress the importance of an improved environmental performance in long-term, improved relations and advantages in implementation. However, there is quite some disagreement about the function of environmental agreements to promote the development and dispersion of new technology, public authorities being optimistic, industry being more reserved.

Environmental associations 28 are primarily concerned about a loss of democratic rights caused by increasing reliance on environmental agreements; they stress the need for accountability, which amounts to the demand for binding agreements and sanctions built into the agreement, transparency and involvement of the civil society. Associations also fear that the negotiation process may be used to water or postpone regulation. Generally they believe that economic interests will be accorded priority and the result of contractual methods may be a stagnation of environmental policy. Therefore they want to limit the contractual approach to supplementing existing regulation or preceding future one rather than using agreements as a substitute for regulation. On the other hand, they recognise that environmental agreements entail important benefits, especially the possibility of using the knowledge of industry for devising tailored solutions and for anticipating regulation on an experimental basis.

When comparing the results of the different member states, the Dutch responses indicate a higher appreciation of the benefits and incentives offered by agreements than do those of the average. This could indicate both the success of Dutch agreements and their perceived legitimacy as an instrument of environmental policy resulting from the accepted social learning model of 
Dutch environmental policy. In any case, inspite of the novelty of the contractual method there seems to exist a basic consensus that under appropriate conditions it is an acceptable instrument of environmental policy.

\section{Arguments}

a) Environmental effectiveness

From an environmental policy perspective, the environmental effectiveness of agreements is paramount. It has two aspects. One is the degree of stringency of the agreement itself in relation to baseline emissions, the reduction potential and possible consumption of improvements by growth, the other is the performance of the parties and hence the success or failure of the agreement.

It is commonly held that there are a number of prerequisites for the conclusion of sufficiently stringent environmental agreements and their environmental success. These prerequisites substantially limit the applicability of contractual techniques, although these factors are not absolute, but relative and not necessarily cumulative: There must be a certain tradition of, and experience with, joint problem-solving; industry and distributors must not expect considerable disadvantages (costs, competitive disadvantages, loss of turnover) as a consequence of the agreement; there must be a certain homogeneity on the part of the committed industry and all major industrial and commercial stakeholders must participate; there must be fairly uniform attitudes in the public as to the assessment of the environmental problem to be solved by the agreement; there must be clear and concrete environmental targets; and the agency must dispose of a credible threatening potential, which means that in case of lack of consensus or compliance with the agreement the adoption of more disadvantageous administrative or economic regulation must be probable 29 .

As regards stringency of the requirements provided by the agreement, it is argued that in order to prevent business-as-usual strategies and watering of environmental targets as well as maintain the political responsibility of the democratic institutions, agreements should only be accepted where they pre-

29 Cf. P. Winsemius, "Environmental Contracts and Covenants: New Instruments for a Realistic Environmental Policy?", in: J. van Dunné, supra note 18, p. 5-15; 1993 Environmental Liability Law Review (TMA) 89-92. 
cede the entering into force of regulation or supplement (concretise or stiffen) it; substitution for regulation should be rejected. To a certain extent this argument is supported by the assumption of negotiation theory that negotiation on objectives is more difficult than that on means to implement given objectives 30 . However, this line of reasoning should not be followed. First of all the delimitation of substitution and concretisation is rather teneous where one deals with broad statutory terms. It has little to do with the political weight of the matter and the interest configuration involved. Also, the notion of regulation soon becomes unclear where one asks the question as to whether political targets, parliamentary statutes or only decrees of the executive qualify as regulation. Finally, there are situations of high complexity associated with great regulatory risk and high coordination costs, e.g., energy saving or recycling of product-related waste, where substitution of agreements for regulation appears appropriate 31 .

It is true that the theoretical consequence of bargaining is that the state must pay, e.g. by a lessening of the desirable level of environmental protection or by promising a standstill of regulation in the foreseeable future. Thus, the German $\mathrm{CO}_{2}$ self-commitment is criticised because it aims at lower energy savings than demanded by the Federal Executive and achieved on the average of the last decades as a consequence of economic change 32 . However, administrative regulation also entails elements of bargaining 33 . One should not take it for granted that a mere prolongation of energy saving trends from the past to the future already represents a valid prognosis (although these trends have at least an indicative value). A recent analysis shows that the energy savings that will probably be achieved by the self-commitment are larger than those associated with the envisaged administrative regulation or $\mathrm{CO}_{2}$ taxes, although a combination of the latter would be superior but amount to very stringent regulation34. Moreover, the drawback of "watering" environmental policy targets may be offset by the advantage that a (prompt) solu-

30 M. Glachand, "Voluntary Agreements in Environmental Policy", OECD 1994, at 10-11 (not published).

31 European Commission, COM (96) 561 final, at No. 15; International Energy Agency, Voluntary Actions for Emission-related CO2 Abatement, OECD 1997, at 62-63.

32 See K. Rennings et al., supra note 23, at 209-210, 213.

33 J. Hucke, "Bargaining in regulative policy implementation: the case of air and water pollution control", 4 Envt'l Pol. \& Law, 109-115 (1978); A. Endres \& M. Finus, "Zur Neuen Politischen Ökonomie der Umweltgesetzgebung - Umweltschutzinstrumente im politischen Prozeß", 9 Zeitschrift für angewandte Umweltpolitik, Special issue 8, 88103 (1996); E. Gawel, Umweltallokation durch Ordnungsrecht, 1994.

34 B. Hillebrand, J. Wachbauer et al., "Gesamtwirtschaftliche Beurteilung von $\mathrm{CO}_{2}$ Minderungsstrategien", IFO 1997, at 60-76. 
tion of the problem is at all possible. Furthermore, due to the acceptance by the most directly affected firms, there may be less compliance problems. This advantage of self-regulation is of a psychological nature. Where industry develops solutions through self-commitments it will later on have to comply with self-created, rather than heteronomous rules; this increases the degree of compliance. However, this requires participation of virtually all affected members of the relevant branch of industry which is not always ensured, for example because small and medium-sized firms are not sufficiently represented in the industrial association.

Finally, the formulation of industry's obligations in an agreement may be an important factor for ensuring a sufficient stringency. Quantified, absolute and detailed obligations are in this respect superior to mere duties to reduce relative (specific) emissions (emissions per product unit) or take best efforts which may be consumed by growth 35 .

It is safe to say that in many European countries some environmental agreements concluded so far have ultimately failed. However, there are more examples of quite successful agreements 36 . Reasons for the failure of agreements have been the great heterogeneity of the participants (e.g. in case of packagings), an inadequate delimitation of the scope of the agreement (e.g. non-inclusion of all important competitors or industrial users of a product), the lack of acceptance of environmentally friendly products by users, lack of substitutes, or the collapse of the calculatory basis of participants due to later developments.

The evidence does not support the argument that self-commitments are doomed to failure because they are not enforceable. However, this is exactly what is sustained by such diverse actors as the European Commission, many authors and environmental associations 37 . A binding contract equipped with

35 European Commission, COM (96) 561 final, at Nos. 20-21; International Energy Agency, supra note 31 , at 52, 65-66.

36 For the Netherlands see Algemeene Rekenkamer, Convenanten van het Rijk met bedrijven en instellingen, 1995; J. Biekart, supra note 18, at 143-148; R. van Acht \& L. Damen, Effectieve toepassing van milieuconvenanten, 1991; E. van Rossum, "Convenanten reviserd", 1993 Environmental Liability Law Review (TMA) 97-102; M. Korten, Overzicht van milieuconvenanten, 1997; for Germany see S. Lautenbach, U. Steger \& P. Weihrauch, in: Bundesverband der Deutschen Industrie, Freiwillige Kooperationslösungen im Umweltschutz - Ergebnisse eines Gutachtens und Workshops, 1992; A. Troge, Erfolgs- und Problemfälle umweltbezogener Selbstverpflichtungen aus der Sicht des Umweltbundesamts, 1997 (unpublished).

37 See European Commission, COM (96) 561 final, at No. 19, but see at No. 11; Rennings et al., supra note 23 , at 144, 165-166, 178; P. Gilhuis, "Zelfregulering en 
sanctions in the form of penalties is the regulatory ideal although it has never been investigated whether the success rate of such agreements is really higher than that of gentlemen's agreements or self-commitments. It also is an open question whether the penalties are really used by the authorities or the state simply reacts to non-compliance by adopting regulation. Finally, the frequency of renegotiation and cancellation provisions in binding agreements indicates certain weaknesses of the contractual approach.

An alternative is the procedural model of social learning which trusts in the strong coercive power of reporting, monitoring and verification, interim targets, transparency and institution building (via joint verification and adjustment bodies). Consequently, many more recent environmental agreements all provide for rather sophisticated monitoring systems; it is thought that the interim monitoring results will enable the state to intervene where there is no reasonable further progress towards achieving the relevant environmental targets.

The question is whether these two models constitute strategic policy options or whether the formal model is the more mature one which will be accepted everywhere once sufficient experience has been gained with the informal method and environmental contracts. have been recognised as in principle being legitimate. I have some doubts because the formal, somewhat legalistic model of reregulation largely equates environmental agreements with negotiated regulation.

\section{b) Efficiency}

Industry favours environmental agreements on the ground that they achieve efficiency gains as compared to both administrative regulation and environmental taxes through their flexibility and consideration of the cost structure of the affected sector. Arguably the major advantage of environmental agreements relates more to equitable distribution of regulatory burdens and avoidance of distortive effects on competition (e.g., dislocation of energy-intensive industry to low energy-efficiency countries, which would run counter to the environmental goal of achieving total net benefits for global climate)38. Since, except for the more recent Dutch agreements, the association commitments are not formally translated into requirements for indi-

milieu", in P. Eijlander, P. Gilhuis \& J. Peters, Regering en Zelfregulering, 1991, p. 71-86.

38 K. Rennings et al., supra note 23, at 214. 
vidual firms, one might assume that part of the alleged efficiency gains achieved by agreements differentiated sector by sector will be lost at firm level39. However, in developing a proposal for an agreement, the relevant industry association largely relies on the individual membership firms' self-assessment of their respective reduction potential. Provided these self-assessments reflect the firms' marginal costs and the firms, because they have a self-interest in the success of the agreement, reduce their emissions accordingly, one cannot rule it out that there are some merits to the efficiency argument.

Another efficiency advantage of agreements as compared to market-based instruments is the greater possibility for industry to foresee and calculate the economic consequences of required reduction of pollution. In particular, industry does not depend on the varying market price of tradeable permits nor does it have to spend money on taxes at the very moment when it would be appropriate to use this money for investment in process changes, and industry is more flexible as regards the exact timing of environmental investments. However, a tiered system of taxation whereby taxes are gradually increased and this increase is announced in advance might have similar advantages.

A related argument in favour of agreements is that they grant industry an option for self-regulation within the framework of targets set by the state. Self-regulation means that industry can shape the design of the relevant rules. This is particularly important in areas such as $\mathrm{CO}_{2}$ reduction and energy efficiency where quite different solutions are possible. Although industry influence on the design of administrative regulation can also be exerted in the bargaining process as to relevant governmental proposals, the "bargaining" position of industry with respect to negotiated self-commitments is better and hence their influence on the design of the solution greater. However, economic instruments are equivalent in this respect.

\section{c) Innovation}

A quite controversial aspect is the relationship of environmental agreements to technological innovation. If one relies on the self-assessment by industry one must conclude that environmental agreements can only be effective

39 K. Rennings et al., supra note 23, at 100, 163, 217; "Deutsches Institut für Wirtschaftsforschung, Selbstverpflichtungen der Wirtschaft zur $\mathrm{CO}_{2}$-Reduktion: Kein Ersatz für aktive Klimapolitik", 62 DIW-Wochenbericht 277, at 279 (1995); but see M. Glachand, supra note 30, at 12; European Commission, COM (96) 561 final, at No. 8; International Energy Agency, supra note 31, at 40-41, 62-64. 
when radical technological innovation is not at stake. On the other hand, it could be argued that voluntary approaches are especially promising in case of technological uncertainties because they give room to social learning. Indeed, environmental agreements in the past have led to technological change at least where substitutes already were in place or research and development was well advanced. The German experience with the voluntary collective recycling system for packaging waste established under the umbrella of the German Packagings Waste Regulation also indicates that environmental agreements may contribute to technological innovation. However, in contrast to environmental taxes, there would not be an ongoing incentive for innovation. To this extent, environmental agreements are close to command-and-control regulation as well as tradeable permits 40 .

\section{d) Conformity with the legal system}

The extent to which environmental agreements can be fit in the relevant legal system raises rather complex legal-political and often highly technical legal questions that vary from country to country and also from type to type of agreement. However, it is nowhere in Europe that one is prepared to unconditionally accept the legality and legitimacy of such agreements 41 . One may object to contractualisation of environmental policy especially on the grounds that the state gives away its regulatory prerogatives and thereby its responsibility for safeguarding the public interest, inequality is promoted, there is a danger of capture of agencies by industry, participation of the public is excluded and competition is restricted 42 .

The two latter aspects are the most important and shall be briefly dealt with. Public participation is generally seen as a major prerequisite for protecting the interests of affected persons, broadening the information basis of the executive, achieving a more rational decision and securing public accep-

40 K. Rennings et al., supra note 23, at 100, 216, 218; M. Kohlhaas \& B. Praetorius, supra note 23 , at 177 ; M. Glachand, supra note 30 , at 14 .

41 This is even true in the Netherlands where environmental agreements are generally accepted; see, e.g. P. van Buuren, "Environmental Covenants: Possibilities and Impossibilities", in: J. van Dunné (ed.), supra note 18, p. 49-55; N. Koeman, supra note 18, at 183-184; I. Koppen, supra note 18, at 166-167 with further references.

42 See, e.g., G. Winter, "Bartering Rationality in Regulation", 19 Law and Society Review 219-250 (1985); W. Rengeling, supra note 4, at 70-71; A. Rest, "The Integration of Environmental Covenants and Contracts in the Public Law System", in: J. van Dunné, supra note 18, p. 225-230; E. Basse, "The Contract Model - The Merits of a Voluntary Approach", 2 Envt'l Liability 74, at 81-82 (1994); C.-A. Morand, "La contractualisation corporatiste de la formation et la mise en oeuvre du droit", in: id. (ed.), L'état propulsif, 1991, p. 181-219. 
tance. In most countries, agreements are negotiated behind closed doors with virtually no public participation, except for isolated press coverage accompanying some more controversial negotiations. To the extent that the executive assumes a major role in the process by initiating and concluding formal agreements or recognising self-commitments, it is arguable that this amounts to a circumvention of the participation requirements for agency decisionmaking.

A universally accepted remedy to the malaise is not in sight. Granting the public the right to participate in the negotiation, for example the right to comment on an advanced draft of the agreement, sit at the negotiation table or even have to give its consent, might impede the success of negotiation. Therefore, it is not amazing that environmental associations who tend to associate environmental agreements with a reduction of democratic rights are split as to the question of participation in the negotiation process; of course, this also is due to manpower problems and a reluctance to assume joint responsibility with industry for the results of the negotiation. The Dutch example shows that in a consensus-oriented society public participation in the negotiation process can function. However even there one finds examples where, for lack of a constructive consensus, environmental associations were excluded from the final stage of the negotiation 43 . This indicates that the participatory model at least has its limitations. An alternative solution for the problem might have to be sought in ex-post controls, e.g. extensive transparence and public participation in monitoring the achievements of the particular agreement. The strong emphasis laid recently on monitoring and transparence of the performance of environmental agreements goes in this direction. The interests of non-participating persons such as suppliers and consumers could then be safeguarded by antitrust enforcement.

Environmental agreements may be associated with restraints of competition where they fix prices, establish pools for collecting and recovering productrelated waste, decide on the introduction of new products, or hamper innovation competition. It also is possible that environmental agreements serve as a shield for participating firms to concert their action with respect to market parameters unrelated to the object of the agreement. Finally, especially the recycling agreements may promote concentration of markets for collection and recovery of waste materials. In the practice of the German and European antitrust authorities, there has been a certain tendency to exempt environmen-

43 See R. Gerits \& J. Hinssen, supra note 18, at 327, 328; furthermore authors cited supra note 20; cf. European Commission, COM (96) 561 final, at No. 18. 
tal agreements -except for price-related agreements and (to a lesser extent) agreements that preclude access to the market - from the scope of application of antitrust laws, on the grounds that the adverse impact on competition was not appreciable or the agreement was on balance beneficial and therefore could be tolerated or formally permitted 44 . Whatever the merits of this permissive balancing approach in individual cases, it is safe to say that the problem of adverse effects on competition can and should be tackled by antitrust enforcement. The discongruence between the mission of antitrust authorities to protect competition and the need for integrating environmental concerns into competition policy has as yet not caused major problems, although especially in Germany one has experienced some tensions. Since most cases do not involve "high politics", an elevation of decision-making powers to the full cabinet would not be appropriate, unless this organisational structure already exists for other reasons, such as in the EC relating to formal exemptions.

Of course, an orthodox antitrust philosophy that does not accept that there may be "reasonable" restraints of competition for the sake of environmental protection, would be the death of environmental agreements. Indeed, one of the main arguments of German critics who adhere to the concept of "Ordnungspolitik" (quasi-constitutional character of the "fundamental" decision for a market economy) against environmental agreements is their principal lack of conformity with the postulates of a market system 45 . This system is said to be constituted by competition occurring within the framework conditions (in our context: environmental framework conditions) to be set by the state rather than private ordering. In this view environmental agreements are a "fall" to which all alternative instruments that are not associated with

44 See, e.g. European Commission, 22nd Report on Competition Policy, 1992, Nos. 77, 179; 23 rd Report on Competition Policy, 1993, Nos. 168, 169, 240; 25th Report on Competition Policy, 1995, No. 85; M. Bock, "Entsorgung von Verkaufsverpackungen und Kartellrecht", 46 Wirtschaft und Wettbewerb 187-203 (1996); A. Riesenkampf, "Die private Abfallentsorgung und das Kartellrecht", 50 Der Betriebs-Berater 933-940 (1995); L. Krämer, "Die Integrierung umweltpolitischer Erfordernisse in die europäische Wettbewerbspolitik", in: W. Rengeling (ed.), Umweltschutz und andere Politiken der Europäischen Gemeinschaft, 1993, p. 47, at 56-58; R. Jacobs, "EEC Competition Law and the Protection of the Environment", 1993 Legal Issues of European Integration 37, at 52-58; T. Portwood, Competition Law and the Environment, 1994; L. Gyselen, "The Emerging Interface between Competition Policy and Environmental Policy in the EC", in D. Cameron, P. Demaret \& D. Geradin (eds.), Trade and Environment - The Search for Balance, 1994, p. 242, at 250-257.

45 K. Rennings et al., supra note 23, at 96, 159, 175, 189-191; G. Maier-Rigaud, "Für eine ökologische Wirtschaftsordnung”, 1996 Jahrbuch Ökologie 71-79; M. Kohlhaas \& B. Praetorius, supra note 23 , at 179 . 
restriction of competition, even administrative regulation, should be preferred.

\section{e) Environmental agreements and the political system}

Under the perspective of political science the trends towards contractualisation of environmental policy seem to conform with the analysis of the structural change of the modern state from hierarchy to dehierarchised policy networks 46 . What tends to spoil the classification of environmental agreements, though, is the predominantly bilateral character of negotiations in most European countries. This adds a certain neocorporatist element 47 . However, environmental contracting is not an emanation of a stable, exclusive relationship between the state and a single powerful industrial association. It is rather based on an ad-hoc selection of suitable negotiation partners. Moreover, the recent efforts at improving transparency of agreements and especially of monitoring results lead to a certain opening to the public at large, especially environmental associations. It is another question whether a stronger public participation in the negotiation process is desirable for increasing the rationality of decision-making, especially safeguarding the interests of affected segments of the population such as suppliers, consumers and workers, and fostering the general interest in environmental protection.

46 See supra notes 5 and 6.

47 In this sense H. Weidner, Umweltkooperation und alternative Konfliktregelungsverfahren in Deutschland, Wissenschaftszentrum Berlin für Sozialforschung, FS II 96-302, 1996, at 44-45; C.A. Morand, supra note 35; P. Lascoumes/J. Valluy, supra note 2, at 25. 


\section{Legalization of environmental agreements?}

The uncertain status of environmental agreements in the legal system as well as the lack of guidance regarding the minimum contents and the procedure to be followed in negotiating such agreements suggest that some general rules in this respect might be desirable.

Denmark and Belgium (Flanders) have made the unique attempt at formally integrating consensual techniques at the level of target setting and implementation into their legal order. Art. 10 and 11 of the Danish Environmental Protection Act of 199348 and the Flemish Decree on Environmental Covenants of 199449 provide for formal authority for the conclusion of such agreements, their relationship to existing or future regulation, their binding force, the entities bound, the (possible) sanctions in case of violation as well as procedural rules; in particular, interested public bodies as well as environmental organisations and in Flanders also other members of the public at large have an opportunity to comment on the draft agreement. This solves a number of controversial legal issues in the debate. However, the practice seems to indicate that industry continues to prefer informal agreements which, in turn, raises the question whether "formalisation of informality" is not so contradictory in itself that it amounts to the quadrature of the circle.

The Flemish example shows that it is problematic to guard against deficiencies of environmental agreements through the adoption of restrictive regulation that somehow equates these agreements with normal administrative regulation. This is in particular true of the procedural requirements that do not only expose the negotiation process to publicity and participation by the public at large, but also entitle important advisory bodies such as the Council on Environment and Nature to comment on the draft and grant the Flemish Parliament a veto right; consequently, the agreement must be published in the official journal. In Denmark especially the binding force of "statutory"

See E. Basse, supra note 42, at 79-84; id., "Environmental Contracts: A New Instrument to be used in the Danish Regulation of Environmental Law", in J. van Dunné (ed.), supra note 18, p. 197-224; J. Jørgensen, "Legislation on 'Eco-Contracts' in Denmark", in: J. van Dunné (ed.), supra note 18, p. 73-85. Both authors reprint the relevant sections of the Danish Environmental Protection Act.

49 Decree No. 94-1787, O.J. of 8 July 1994, p. 180; for the draft see H. Bocken, "Covenants in Belgian Environmental Law - Remarks on the Draft Decree on Environmental Covenants", in J. van Dunné, supra note 18, p. 57-71; H. Bocken \& D. Ryckbost (ed.), Codification of Environmental Law - Draft Decree on Environmental Policy, 1996, p. 191-194. 
agreements is not accepted by industry. Moreover, except for one case where a serious freerider problem existed and industry was interested in having it solved (lead batteries), the freerider provision whereby also firms that do not participate in the agreement are under certain circumstances bound by it has deterred industry from using the new law.

By contrast, more flexible approaches such as those used in Portugal (limited to compliance agreements) and the Netherlands seem to function better. In Portugal, industry and the competent ministries signed a protocol of understanding whereby firms that do not adhere to an environmental agreement are required to strictly conform to environmental regulations and, unlike signatory firms, are neither granted delays for compliance nor financial assistance. The Netherlands rejected the idea of general legislation because it was felt that the advantages of the contractual model - flexibility and freedom as to procedure and content - would be lost. Instead the Netherlands adopted a provisional code of conduct which contains recommended criteria for the contents of environmental agreements and the procedure for their negotiation and conclusion50. In Portugal, 8 agreements have been concluded on the basis of the Protocol; in the Netherlands, the number is 12 .

This also is the method followed by the European Commission in its Communication and its Recommendation on environmental agreements. However, it should be noted that the flexibility of the method - instead of mandatory regulation mere indicative criteria - does not necessarily mean that the criteria as such are acceptable. In this respect, as already stated the European Commission's insistence on binding contracts and its preference even for outright sanctions appears problematic.

50 See also the Guidelines of the Prime Minister (Ministry of General Affairs) for the conclusion of agreements between the government and private parties, 1995 Staatscourant 249. 


\section{Biographical Note}

Professor ECKARD REHBINDER was born in 1936 and studied Law in Frankfurt/Main and Berlin. He received his Ph.D. (Dr. jur.) in 1965 and became "Privatdozent" in 1968 at the Law Faculty of the University of Frankfurt/Main. He presently is Professor of Business Law, Environmental Law and Comparative Law at Frankfurt Law Faculty and Codirector of the Research Center for Environmental Law and the Institute for Foreign and International Trade Law. He is Chairman of the German Council of Environmental Advisors and member of various environmental bodies, such as the Commission of Law of the International Union for the Conservation of Nature and Natural Resources and the Conseil Européen de Droit de l'Environnement. $\mathrm{He}$ has served as a visiting professor at the University of California Law Sehool (Berkeley), University of Michigan Law School (Ann Arbor) and several times at the European University Institute.

His more recent publications include Environmental Protection Policy (1985, together with R. Stewart, volume 2 of the series Integration Through Law. Europe and the American Federal Experience, edited by M. Cappelletti et al.), Umweltgesetzbuch - Allgemeiner Teil (1991, together with M. Kloepfer et al.), Umweltgesetzbuch - Besonderer Teil (1994, together with D. Jarass et al.), Umweltzertifikate und Kompensationslösungen aus ökonomischer und juristischer Sicht (1994, together with A. Endres and R. Schwarze), "Precaution and Sustainability: Two Sides of the Same Coin?" (1994, in A Law for the Environment, edited by A. Kiss \& F. Burhenne-Guilmin), and "Selfregulation by Industry" (1995, in European Environmental Law, edited by G. Winter) 


\section{Jean Monnet Chair Papers}

\section{European University Institute, Florence}

\begin{abstract}
1. CHRISTOPH BERTRAM/Sir
JULIAN BULLARD/

LORD COCKFIELD/ Sir DAVID

HANNAY/MICHAEL PALMER

Power and Plenty? From the

Internal Market to Political and

Security Cooperation in Europe, April 1991,pp. 73
\end{abstract}

\section{ROBERT GILPIN}

The Transformation of the International Political Economy, April 1991, pp.27

\section{EDMOND MALINVAUD}

Macroeconomic Research and European Policy Formation, April 1991, pp. 58

\section{SERGIO ROMANO}

Soviet Policy and Europe Since Gorbachev, April 1991, pp. 25

\section{BERNT VON STADEN}

The Politics of European Integration, April 1991, pp. 33

\section{HELGA HAFTENDORN}

European Security Cooperation and the Atlantic Alliance, July 1991, pp. 42

\section{THOMAS}

ANDERSSON/STAFFAN

BURENSTAM LINDER

Europe and the East Asian

Agenda,

October 1991, pp. 87
8. ROGER G. NOLL

The Economics and Politics of

Deregulation,

October 1991, pp. 89

9. ROBERT TRIFFIN

IMS International Monetary

System - or Scandal?,

March 1992, pp. 49

10. EGON BAHR

From Western Europe to Europe, June 1992, pp. 42

\section{HELGE HVEEM}

The European Economic Area and the Nordic Countries - End Station or Transition to EC Membership?, June 1992, pp. 21

12. ERIC STEIN

Post-communist Constitutionmaking: Confessions of a Comparatist (Part I), August 1992, pp. 63

13. CAROLE FINK 1922/23 From Illusion to Disillusion, October 1992, pp. 19

14. LOUIS H. ORZACK International Authority and Professions. The State Beyond The Nation-State, November 1992, pp. 47 
15. VLADIMIR M. KOLLONTAI Economic Reform in Russia, November 1992, pp. 43

\section{RYUTARO KOMIYA} Japan's Comparative Advantage in the Machinery Industry: Industrial Organization and Technological Progress, October 1993, pp. 60

\section{GIULIANO AMATO}

Problems of Governance - Italy and Europe: A Personal Perspective, October 1994, pp. 39

\section{JEREMY RICHARDSON}

The Market for Political Activism: Interest Groups as a Challenge to Political Parties, November 1994, pp. 37

\section{RICHARD B. STEWART}

Markets versus Environment?, January 1995, pp. 53

20. JOHN GERARD RUGGIE At Home Abroad, Abroad at Home: International Liberalization and Domestic Stability in the New World Economy, February 1995, pp. 64

\section{DAVID VOGEL}

The Relationship Between Environmental and Consumer Regulation and International Trade, February 1995, pp. 44

22. JOHN WILLIAMSON

Proto-EMU as an Alternative to Maastricht, March 1995, pp. 20

\section{THOMAS C. HELLER} Joint Implementation and the Path to a Climate Change Regime, March 1995, pp. 49

\section{NORMAN SCHOFIELD}

Modelling Political Order in Representative Democracies, June 1995, pp. 38

\section{VOJIN DIMITRIJEVIC}

The Fate of Non-Members of Dominant Nations in PostCommunist European Countries, June 1995, pp. 34

\section{HORST SIEBERT}

Eastern Germany in the Fifth Year. Investment Hammering in the Basement?, September 1995, pp. 45

\section{CAROL HARLOW} Codification of EC Administrative Procedures? Fitting the Foot to the Shoe or the Shoe to the Foot,

September 1995, pp. 34

\section{FRITZ W. SCHARPF}

Negative and Positive Integration in the Political Economy of European Welfare States, November 1995, pp. 44

29. VINCENT WRIGHT Industrial and Banking Privatization in Western Europe: Some Public Policy Paradoxes, November 1995, pp. 40 
30. ROBERT O. KEOHANE

Local Commons and Global

Environmental Interdependence:

Tragedy of the Commons or

Opportunity for Institutions?,

November 1995, pp. 21

\section{S ABINO CASSESE}

The Difficult Profession of

Minister of Public

Administration,

December 1995, pp. 31

32. MANCUR OLSON JR.

The Varieties of Eurosclerosis:

The Rise and Decline of Nations

since 1982,

December 1995, pp. 37

33. ROD A.W. RHODES

Towards a Postmodern Public

Administration: Epoch,

Epistemology or Narrative?,

December 1995, pp. 49

34. MARTIN SHAPIRO

Independent Agencies:

US and EU,

April 1996, pp. 31

\section{S ASKIA S ASSEN}

The De-Facto Transnationalizing of Immigration Policy, April 1996, pp. 36

36. JoSÉ MARÍA MARAVALL

The Outcomes of Democracy, April 1996, pp. 53

\section{PIERRE ROSANVALLON}

État-providence et citoyenneté sociale,

September 1996, pp. 27
38. PETER B. KENEN

Sorting Out Some EMU Issues, October 1996, pp. 36

39. En hommage à ÉMILE NOËL, December 1996, pp. 21

40. TOMMASO PADOA-

SCHIOPPA

The Genesis of EMU: A

Retrospective View,

December 1996, pp. 21

41. GIL CARLOS RODRIGUEZ IGLESIAS

Le pouvoir judiciaire de la Communauté européenne au stade actuel de l'évolution de l'Union,

December 1996, pp. 27

42. WOLFGANG STREECK

Citizenship under Regime

Competition: The Case of the "European Works Councils", April 1997, pp 49

\section{NiCOle QUESTIAUX}

Le Conseil d'État français et la norme communautaire:

l'hybridation en tant que technique juridique,

May 1997, pp 25

44. PAUL PIERSON

Increasing Returns, Path

Dependence and the Study of

Politics,

June 1997, pp 47

\section{ECKARD REHBINDER}

Environmental Agreements -

A New Instrument of

Environmental Policy, August 1997, pp 37 


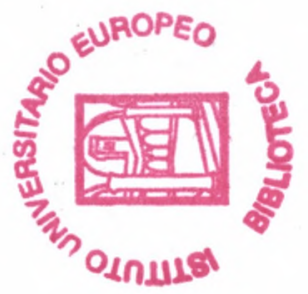

